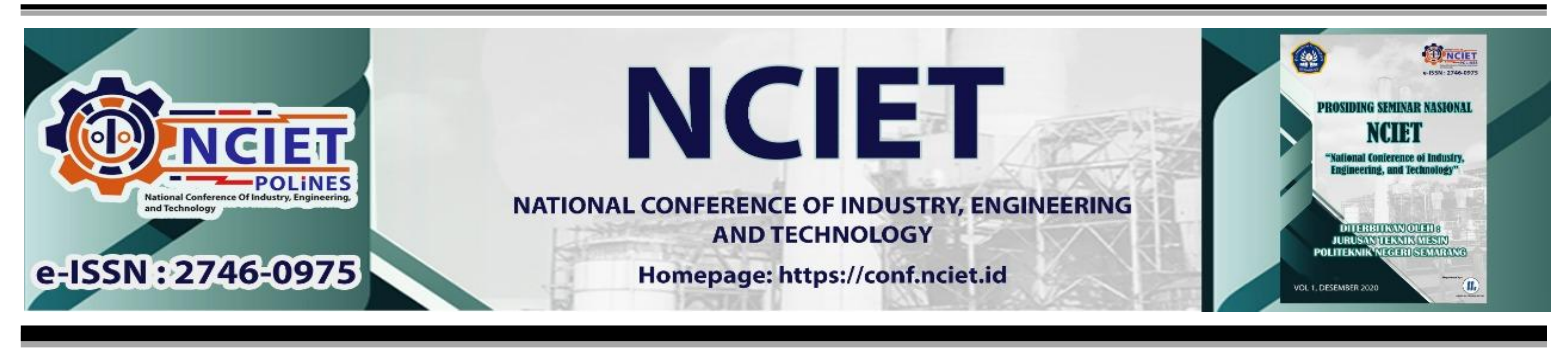

Prosiding Seminar Nasional NCIET Vol.1 (2020) B242-B250

$1^{\text {st }}$ National Conference of Industry, Engineering and Technology 2020,

Semarang, Indonesia.

\title{
OPEN CIRCUIT VOLTAGE PADA REVERSE ELECTRODIALYSIS POWER GENERATION DENGAN ELEKTRODA CARBON MICROPARTICLE
}

\author{
Suka Handaja ${ }^{1,2 *}$,Heru Susanto $^{3}$, Hermawan $^{4}$ \\ ${ }^{1}$ Program Doktor Ilmu Lingkungan, Universitas Diponegoro \\ Jl. Imam Bardjo SH No. 5 Semarang, 50241 \\ ${ }^{2}$ Program Studi Teknik Instrumentasi Kilang, Politeknik Energi dan Mineral Akamigas \\ Jl. Gajah Mada No. 38 Cepu, Blora, 58315 \\ ${ }^{3}$ Program Studi Teknik Kimia, Fakultas Teknik, Universitas Diponegoro \\ ${ }^{4}$ Program Studi Teknik Elektro, Fakultas Teknik, Universitas Diponegoro \\ Jl. Prof. Soedarto, SH, Tembalang,Semarang, 50275 \\ *E-mail : suka.hb@gmail.com
}

\begin{abstract}
Abstrak
Reverse Electrodialysis Power Generation (RED) adalah pembangkit listrik yang mengkonversikan energi percampuran dua larutan berbeda salinitas menjadi energi listrik. RED dibuat dari membrane selective ion yang disusun berselang seling antara membran AEM dan CEM. Larutan berbeda salinitas dialirkan berselang seling di celah celah membran sehingga terdapat aliran ion. Untuk mengkonversikan aliran ion menjadi aliran elektron diperlukan elektroda. Pada artikel ini elektroda yang dipakai adalah elektroda carbon microparticle. Elektroda carbon microparticle merupakan elektroda alternatif pada RED yang biasanya menggunakan Ti Base. Larutan bersalinitas disimulasikan dari $\mathrm{NaCl}$ berkonsentrasi $1 \mathrm{gr} / \mathrm{L}$ untuk larutan encer dan $\mathrm{NaCl}$ berkonsentrasi $30 \mathrm{gr} / \mathrm{L}, 35 \mathrm{gr} / \mathrm{L}$ dan $40 \mathrm{gr} / \mathrm{L}$ untuk larutan pekat. Open Current Voltage RED yang diperoleh adalah $70 \%$ dari OCV teoritis, hal ini disebabkan karena adanya hambatan ion karena sifat material yang ada pada membran, elektroda dan larutan bersalinitas. Terjadi penurunan OCV akibat penurunan performance membran yang disebabkan oleh lamanya waktu operasi RED dengan besar penurunan 17\%/jam. Semakin besar kecepatan aliran menyebabkan besar OCV yang terukur juga semakin besar atau penurunan OCV semakin kecil dengan bertambahnya kecepatan aliran larutan. Penurunan OCV yang disebabkan pemanfaatan elektroda carbon microparticle tidak terlihat karena nilai resistivitasnya yang kecil sehingga elektroda carbon microparticle dapat dipergunakan sebagai altenatif pengganti elektroda berbasis tungten (Ti).
\end{abstract}

Kata Kunci: Reverse Electrodialysis; RED; Elektroda Karbon; Open Circuit Voltage

\section{PENDAHULUAN}

Reverse Electrodialysis Power Generation (RED) merupakan pembangkit energi terbarukan yang ramah lingkungan. RED tidak memerlukan peralatan yang bergerak atau berputar serta tidak menghasilkan emisi $\mathrm{CO}_{2}$ (Cipollina \& Micale, 2016)(Gilstrap, 2013). RED merupakan teknologi pembangkitan listrik dengan mengkoversi energi dari 
percampuran cairan yang berbeda salinitasnya (Post, et al., 2007). RED dapat diterapkan untuk mengasilkan listrik dengan sumber cairan berasal dari air laut untuk larutan bersalinitas tinggi dan air sungai untuk larutan bersalinitas rendah (Tedesco, et al., 2015). RED merupakan kebalikan sistem elektrolisa, jika sistem elektrolisa memerlukan sumber energi listrik dalam prosesnya sedangkan RED menghasilakan listrik dari prosesnya. Stack RED dibuat dari membrane selective ion yang disusun berselang seling antara AEM (Anode Exchange Membrane) dan CEM (Cathode Exchange Membrane) dan mengalirkan larutan bersalinitas berbeda yang berselang seling juga diantara membran seperti terlihat pada gambar 1. Di ujung stack terdapat sistem elektroda yaitu terdiri dari elektroda beserta current collector untuk mengalirkan arus listrik serta electrode rinse solution (ERS) yang berfungsi sebagai pembilas ion pada elektroda yaitu mengalirkan ion dari anoda ke katoda (Castaño \& Sáenz, 2017) (Veerman, Saakes, Metz, \& Harmsen, 2010).

Jika dua larutan yang berbeda salinitas dicampurkan maka akan terjadi pelepasan energi, energi ini biasanya disebut energi bebas Gibbs ( $\Delta G$ ) (Pattle, 1954) (Vermaas, Guler, Saakes, \& Nijmeijer, 2012). Untuk larutan garam murni monovalen, energi bebas Gibbs dari pencampuran cairan antara konsentrasi garam rendah dan larutan garam konsentrasi tinggi dinyatakan dalam :

$$
\begin{aligned}
\Delta G & =2 R T\left[V_{L} C_{L} \ln \frac{C_{L}}{C_{M}}+V_{H} C_{H} \ln \frac{C_{H}}{C_{M}}\right] \\
C_{M} & =\frac{V_{L} C_{L}+V_{H} C_{H}}{V_{L}+V_{H}} \quad\left(\text { mol.m } m^{-3}\right)
\end{aligned}
$$

Dengan $V$ volume larutan $\left(\mathrm{m}^{3}\right)$, dan $C$ adalah konsentrasi $\left(\mathrm{mol} / \mathrm{m}^{3}\right), R$ adalah kontanta gas universal yang nilainya sebesar $8.31 \mathrm{~J} / \mathrm{mol} . \mathrm{K}), T$ adalah temperature absolut (K), subscript $L$ untuk larutan konsentrasi rendah, $H$ untuk larutan konsentrasi tinggi, $M$ untuk larutan campuran akhir.

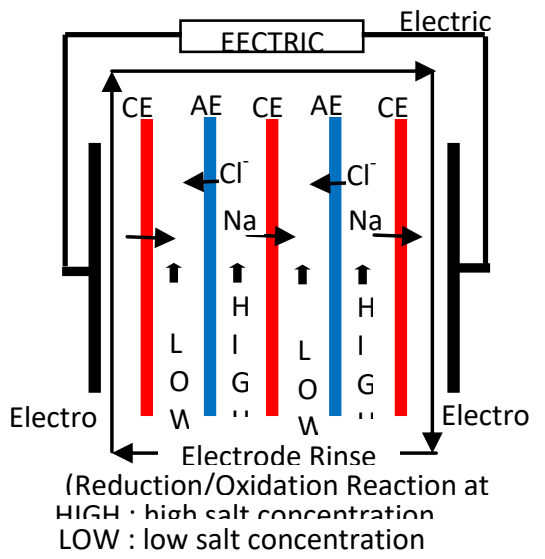

Gambar 1. Skema Stack RED 2 Cells 
Jika larutan berbeda salinitas dialirkan di celah celah membran selektif ion, akan menyebabkan larutan bersalinitas tinggi mengalir ke larutan bersalinitas rendah. Saat larutan mengalir menembus membran selektif ion, membran selektif ion akan memfilter ion yang mengalir, ion positif akan lolos melalui CEM dan ion negatif akan terfilter, sebaliknya ion negatif akan lolos melalui membran AEM dan ion positif akan terfilter sehingga terdapat konsentrasi ion pada elektroda, pada elektroda terdapat proses reduksi dan oksidasi (redoks) yang mengkonversikan ion menjadi elektron yang selanjutnya jika sistem diberi beban listrik maka elektron akan mengalir ke beban listrik (Weiner, McGovern, \& Lienhard V, 2015).

Besar beda potensial listrik yang dihasilkan oleh sistem RED telah diformulasikan oleh Nernst yang dituliskan dalam persamaan berikut :

$$
E=N_{m} \alpha \frac{R T}{z F} \ln \left(\frac{\gamma_{\text {sea }} c_{\text {sea }}}{\gamma_{\text {river }} c_{\text {river }}}\right)
$$

Dengan $E$ adalah beda potensial (Volt), $N m$ adalah jumlah pasangan membran, $\alpha$ adalah konstanta selektivitas membran, $R$ adalah konstanta gas universal $8.31 \mathrm{~J} / \mathrm{mol}$. K), $\mathrm{T}$ adalah temperature absolut $(\mathrm{K}), \mathrm{z}$ adalah valensi ion, $F$ adalah konstanta Faraday (96485 $\mathrm{C} / \mathrm{mol}$ ), $\gamma$ adalah koefisien aktivitas ion, $\mathrm{c}$ adalah konsentrasi larutan dan subscript sea untuk air laut, river untuk air sungai.

Besar tegangan keluaran RED yang dituliskan Nernst merupakan beda potensial keluaran teoritis. Besar beda potensial sangat dipengaruhi oleh konsentrasi larutan, sedangkan konsentrasi larutan yang berada di celah-celah membran sangat dipengaruhi oleh laju aliran serta profile aliran dalam menembus membran, jika diformulasikan akan melibatkan persamaan yang rumit (Tedesco, et al., 2015). Jika beda potensial diukur di masing-masing ujung current collector pada elektroda, yang terukur akan mengalami penurunan tegangan. Hal ini disebabkan adanya losses tegangan yang diakibatkan oleh hambatan listrik yang berasal dari air bersalinitas, membran dan elektroda. Dalam hal sistem RED tidak diberi beban maka tegangan keluaran RED disebut OCV (Open Current Voltage), yang artinya beban RED hanya berupa alat ukur tegangan yang nilai hambatannya sangat besar sehingga tidak ada arus listrik yang mengalir ke alat ukur atau dalam keadaan open current.

Dari uraian diatas dapat diketahui bahwa besar tegangan open current (OCV) dipengaruhi oleh banyak parameter diantaranya laju aliran, konsentrasi aliran, hambatan listrik larutan, membran dan elektroda. Dalam artikel ini penulis melakukan analisa besar 
OCV pada RED yang menggunakan elektroda carbon microparticle dengan mengukur tegangan OCV pada RED dengan memvariasi laju aliran larutan dengan konsentrasi yang telah ditentukan. Elektroda carbon terutama graphite telah dipakai sebagai elektroda pada RED namun demikian elektroda karbon dalam ukuran microparticle belum pernah diaplikasikan. Oleh karena itu penelitian ini dilaksanakan dengan tujuan untuk mengetahui efektifitas pemanfaatan elektroda carbon nanoparticle pada RED

\section{METODE PENELITIAN}

Pada artikel ini dibuat dua sel RED seperti gambar 2 menggunakan membran Selemion $^{\mathrm{TM}}$ tipe komersial (CEM/CMS, AEM/AMS), spacer menggunakan nylon woven dan gasket menggunakan silikon. Membran Selemion ${ }^{\mathrm{TM}}$ diperoleh dari AGC Engineering Co. Ltd. Chiba Jepang, Nylon Woven dari Sefar HG, Heiden Switzerland dan Silicon dari Sikisei Company Ltd (Susanto, Fitrianingtyas, Samsudin, \& Syakur, 2017). Elektroda yang digunakan adalah elektroda yang terbuat dari campuran batang karbon dan pasta elektrolit baterai bekas yang telah dibuat dalam ukuran partikel dibawah 1 micrometer dengan pengumpul arus menggunakan wire mesh dari stainless steel. Sebagai sumber larutan digunakan $\mathrm{NaCl}$ dari Pudak Scientific Indonesia. Untuk larutan salinitas konsentrasi rendah (larutan encer) digunakan larutan $\mathrm{NaCl} 1 \mathrm{gr} / \mathrm{L}$ dan untuk larutan salinitas konsentrasi tinggi (larutan pekat) digunakan $\mathrm{NaCl} 30 \mathrm{gr} / \mathrm{l}, 35 \mathrm{gr} / \mathrm{L}$ dan 40 gr/L sedangkan untuk larutan bilas elektroda digunakan larutan $\mathrm{NaCl}$ konsentrasi 14,5 gr/L.

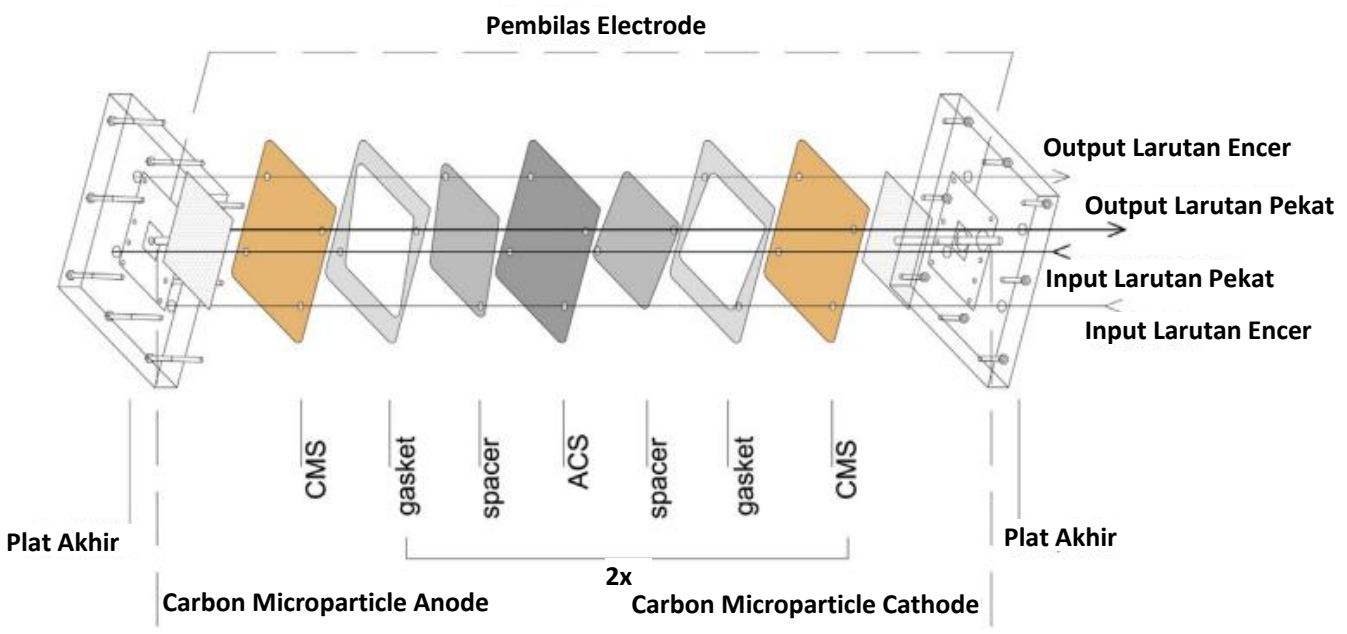

Gambar 2. Rangkaian Stack RED 2 cells

Stack RED seperti Gambar 2 dibuat dengan ukuran $12 \times 12 \mathrm{~cm}^{2}$ dan rangkaian percobaan dibuat seperti Gambar 3. Untuk mengukur tegangan digunakan multimeter 
(Yokogawa CA71 Handy Cal) sedangkan untuk pengukuran kecepatan aliran digunakan flowmeter (Dwyer Instrument ).

Eksperimen diawali dengan memberikan aliran pada sistem RED menggunakan larutan pekat $30 \mathrm{gr} / \mathrm{l}$ dengan kecepatan aliran $50 \mathrm{ml} /$ menit dan kecepatan aliran larutan encer 50 $\mathrm{ml} /$ menit dan aliran bilas elektroda $50 \mathrm{ml} / \mathrm{menit}$. Pada aliran ini tegangan keluaran RED diukur selama 1 jam dengan periode perekaman setiap 10 menit selama 1 jam. Selanjutnya kecepatan aliran larutan pekat diubah menjadi $75 \mathrm{~mL} / \mathrm{menit}$ dan kecepatan aliran larutan encer dan larutan bilas elektroda tetap, pengukuran tegangan dilakukan seperti sebelumnya. Selanjutnya dilakukan percobaan yang sama dengan mengatur kecepatan aliran larutan pekat menjadi $100 \mathrm{~mL} /$ menit sedangkan kecepatan aliran larutan encer dan larutan bilas elektroda tetap. Untuk selanjutnya dilakukan eksperimen untuk larutan pekat $35 \mathrm{gr} / \mathrm{L}$ dan $40 \mathrm{gr} / \mathrm{L}$ seperti langkah eksperimen dengan larutan pekat $30 \mathrm{gr} / \mathrm{L}$. Sebelum melaksanakan pergantian larutan pekat, stack RED di flashing menggunakan air suling dengan kecepatan alir $50 \mathrm{~mL} / \mathrm{menit}$ untuk mengembalikan pada kondisi awal, flashing dilakukan dua kali masing masing 1 jam.

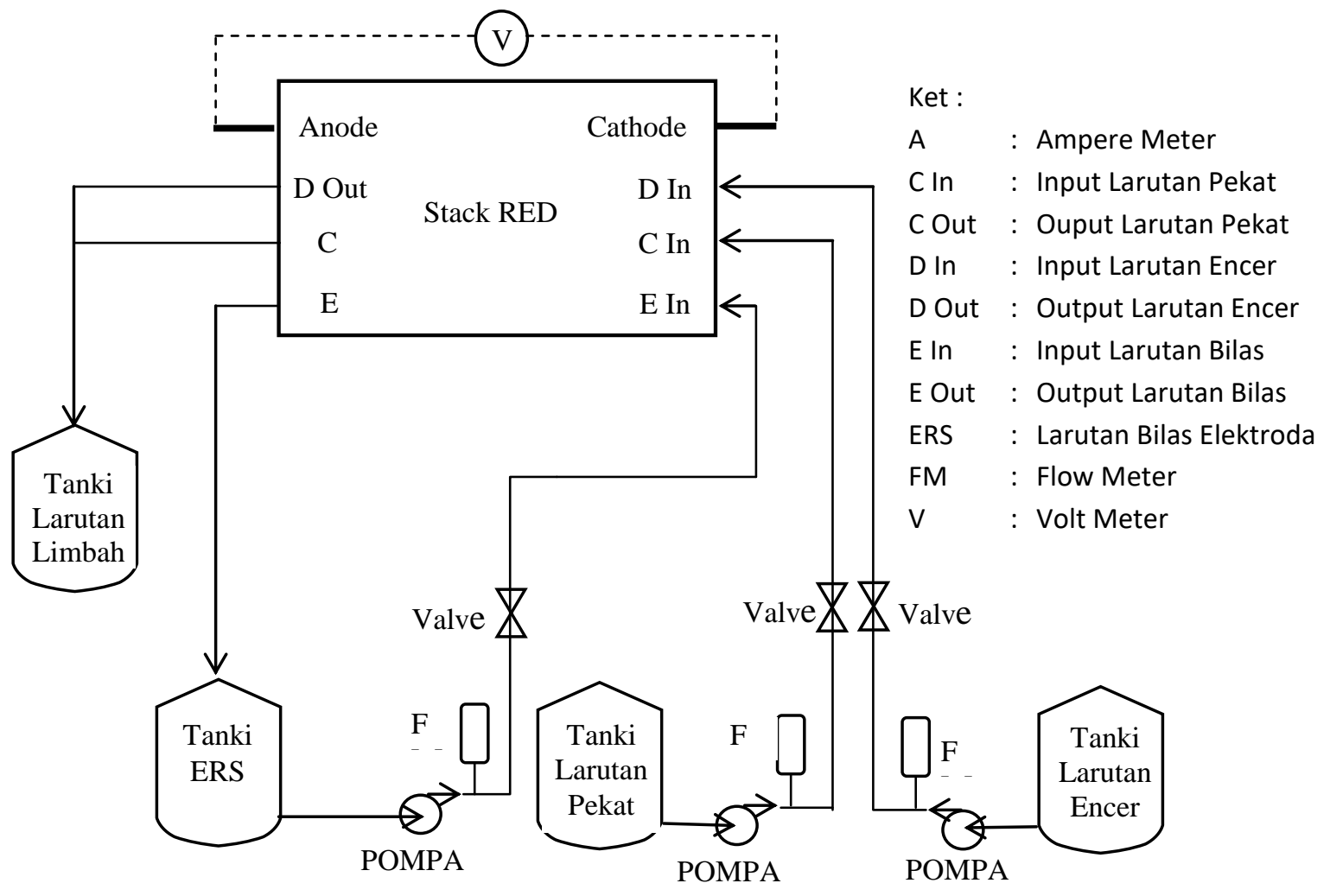

Gambar 3. Rangkaian Pengujian Karakteristik Reverse Electrodialysis Power Generation 


\section{HASIL DAN PEMBAHASAN}

Stack RED dibuat dengan ukuran $12 \times 12 \mathrm{~cm}^{2}$ sebanyak 2 cells $\left(720 \mathrm{~cm}^{2}\right)$ dengan menggunakan membran yang dibuat oleh Selemion ${ }^{\mathrm{TM}}$ dengan spesifikasi seperti tabel 1. Stack RED disusun seperti gambar 2 dengan menggunakan co-current (arah aliran larutan pekat dan larutan encer searah)

Menurut Nernst, koefisien selektivitas sangat mempengaruhi besar keluaran OCV. Koefisien selektivitas adalah kemampuan membran dalam meloloskan ion sesuai dengan fungsinya. Jika koefisien selektivitas memiliki nilai 0,96 artinya terdapat $4 \%$ kebocoran ion yang seharusnya di filter oleh membran. Dengan spesifikasi membran pada tabel 1 , besar OCV secara teoritis dapat dihitung dengan persamaan 2 yang diperoleh untuk larutan pekat dengan konsentrasi $30 \mathrm{gr} / \mathrm{L}$ memiliki nilai 0,334 Volt sedangkan untuk larutan pekat $35 \mathrm{gr} / \mathrm{L}$ dan $40 \mathrm{gr} / \mathrm{L}$ adalah 0,349 Volt dan 0,362 Volt. Secara teoritis, semakin besar perbedaan salinitas antara larutan encer dan larutan pekat, nilai OVC juga akan semakin meningkat hal ini terlihat dari hasil perhitungan sesuai persamaan 2 dan diperlihatkan pada gambar 4.D.

Tabel 1 : Spesifikasi Membrane Selective Ion Selemion ${ }^{\mathrm{TM}}$

\begin{tabular}{llcc}
\hline \multicolumn{1}{c}{ Spesifikasi } & Cation & Anion \\
\hline Nama Produk & & CMS & AMS \\
Karakteristik & & Standar & Standar \\
Penggunaan & & 110 & ED \\
Ketebalan $(\mu \mathrm{m})$ & & 200 & 200 \\
Kekuatan Tekan $(\mathrm{kPa})$ & & 3,0 & 2,8 \\
Resistivitas $\left(\mathrm{Ohm} . \mathrm{m}^{2}\right)$ & $0.5[\mathrm{~mol} / \mathrm{L}] \mathrm{NaCl}$ & $>0,96$ & \\
& $\mathrm{t}-\mathrm{Na}^{+}$ & & $>0,96$ \\
Koefisien Selektivitas & $\mathrm{t}-\mathrm{Cl}^{-}$ & & \\
&
\end{tabular}

Sumber : AGC Engineering Co. Ltd. Chiba Jepang

Hasil pengukuran OCV untuk beberapa konsentrasi larutan pekat dengan beberapa variasi kecepatan aliran ditunjukkan pada gambar 4. Terlihat pada gambar 4 bahwa nilai OCV pada eksperimen lebih rendah daripada nilai OCV teoritis. Bila kita bandingkan antara nilai OCV teoritis dengan OCV yang terukur pada eksperimen, nilai OCV yang terukur adalah sekitar $70 \%$ nilai OCV teoritis artinya terdapat penurunan tegangan sebesar $30 \%$. Selain itu berdasarkan kurva waktu terlihat bahwa selama 1 jam pengamatan terdapat penurunan tegangan sebesar $17 \%$. Ada beberapa penyebab adanya penurunan tegangan pada RED meskipun tidak ada aliran listrik yang mengalir ke beban. Karena prinsip kerja aliran ion pada RED didasari adanya perbedaan konsentrasi larutan maka 
selama terdapat perbedaan salinitas maka ion akan mengalir dari salinitas tinggi ke salinitas rendah. Ion yang mengalir mengakibatkan adanya beda potensial pada sistem RED. Oleh karena itu dapat dijelaskan bahwa penurunan tegangan dapat disebabkan oleh karena adanya gangguan aliran ion. Aliran ion dapat terganggu jika membran mengalami penurunan performance misal adanya kebuntuan, jika membran mengalami kebuntuan mengakibatkan nilai koefisien selektivitas membran akan menurun yang mengakibatkan adanya penurunan beda potensial, hal itu terkonfirmasi dari gambar 4.A, B dan C dimana nilai OCV mengalami penurunan terhadap waktu.
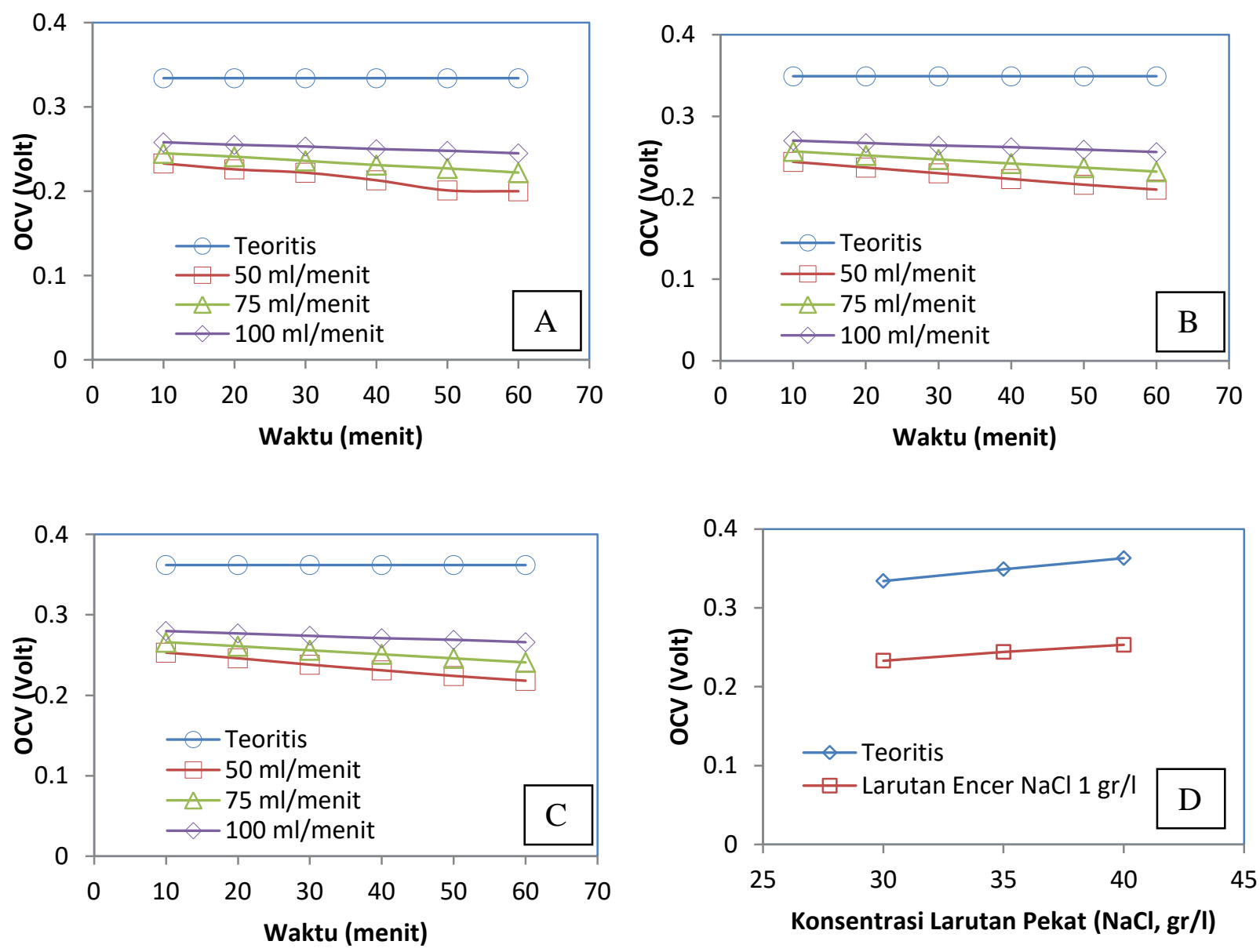

Gambar 4. Plot nilai OCV RED dengan larutan encer $\mathrm{NaCl} 1 \mathrm{gr} / \mathrm{L}$ pada berbagai kecepatan aliran dan beberapa larutan pekat serta pada larutan bilas 14,5 gr/L, (A) Untuk larutan pekat $\mathrm{NaCl} 30$ gr/L., (B) Untuk Larutan pekat 35 gr/L., (C) Untuk Larutan pekat NaCl 40 gr/L., (D) Untuk kecepatan aliran $50 \mathrm{~mL} / \mathrm{menit}$

Penurunan tegangan dapat berkurang dengan semakin cepatnya kecepatan aliran larutan, hal ini disebabkan dengan semakin cepatnya aliran larutan maka konsentrasi larutan yang berada di celah-celah membran akan segera ter-recovery sehingga konsentrasi 
larutan tetap terjaga pada nilai optimumnya. Hal tersebut terkonfirmasi pada gambar 4, dimana pada kecepatan aliran larutan pekat $100 \mathrm{~mL} / \mathrm{menit}$ memberikan trend penurunan tegangan yang lebih landai dibandingkan dengan trend pada kecepatan larutan pekat 75 $\mathrm{mL} / \mathrm{menit}$ dan $50 \mathrm{~mL} / \mathrm{menit}$.

Besarnya selisih OCV teoritis dan eksperimen juga dapat disebabkan oleh adanya hambatan listrik pada membran, elektroda dan larutan encer maupun larutan pekat. Hal tersebut terlihat dari adanya perbedaan nilai OCV secara teoritis dengan OCV yang terukur seperti di gambar 4. Oleh karena sifat materialnya yang memiliki resistivity (menghambat aliran elektron/ion) mengakibatkan saat ion melewati membran tidak semua ion terloloskan dan mengakibatkan jumlah ion yang mengalir akan berkurang, demikian juga yang terjadi pada larutan pekat dan encer serta elektroda. Dilihat dari besarnya hambatan listrik, dari ke-empat komponen tersebut besar resistivity elektroda carbon microparticle adalah yang terkecil yaitu sebesar 0,364 Ohm.cm dibandingkan dengan resistivity membran maupun resistivity larutan dan juga jumlah keping elektroda yang dibutuhkan dalam sebuah stack RED hanya dua yaitu untuk anoda dan katoda sedangkan jumlah keping membran lebih banyak tergantung dari jumlah cell, demikian pula dengan hambatan yang disebabkan oleh larutan, semakin banyak jumlah cell akan menambah panjang aliran larutan yang mengakibatkan semakin besar hambatan listriknya. Meskipun pengaruh elektroda terhadap penurunan OCV tidak terlalu besar bahkan bisa diabaikan, elektroda dengan resitivity yang kecil sangat dibutuhkan untuk mengurangi penurunan tegangan saat RED diberi beban, untuk hal tersebut penelitian lanjut terkait pengaruh elektroda saat RED diberi beban listrik perlu dilakukan.

\section{KESIMPULAN}

Telah dilakukan eksperimen karakteristik nilai OCV RED dengan menggunakan elektroda carbon microparticle. Dari hasil eksperimen dan pembahasan dapat disimpulkan bahwa RED merupakan teknologi recovery energi yang memiliki potensi yang besar untuk dikembangkan. Besar OCV RED dipengaruhi oleh perbedaan konsentrasi larutan, semakin besar beda salinitasnya maka OCV semakin besar, semakin besar kecepatan alir larutan akan menurunkan penurunan OCV, semakin besar resistansi membran, larutan dan elektroda maka selisih OCV teoritis dan OCV eksperimen akan semakin besar. Kontribusi selisih OCV teoritis dan OCV eksperimen dari pemanfaatan elektroda microparticle tidak terlalu besar bahkan bisa diabaikan yang berarti elektroda carbon microparticle dapat 
dipakai sebagai alternatif elektroda. Untuk mengetahui lebih lanjut pemanfaatan elektroda carbon microparticle perlu dikembangkan penelitian dengan menggunakan beban listrik serta pengamatan untuk selang waktu yang lebih lama dengan jumlah cell yang lebih besar serta memanfaatkan larutan encer dan pekat yang sebenarnya yaitu air laut dan air sungai.

\section{DAFTAR PUSTAKA}

Castaño, V., \& Sáenz, S. (2017). Design and optimization of a reverse electrodialysis stack for energy generation through salinity gradients. Revista DYNA, 84(202), ISSN 00127353, 84-91.

Cipollina, A., \& Micale, G. (2016). Sustainable Energy from Gradient Salinity. Cambidge USA: Woodhead Publishing.

Gilstrap, M. C. (2013). Renewable Electric Generation From Salinity Gradient Using Reverse Electrodialysis. Georgia: School of Civil \& Environmental Engineering Georgia Institue of Technology.

Liu, F., Coronell, O., \& Call, D. F. (2017). Electricity generation using continuously recirculated flow electrodesin reverse electrodialysis. Journal of Power Sources 355, 206-210.

Pattle, R. (1954). Production of electric power by mixing fresh and salt water in the hydroelectric pile. Nature (174), 655-662.

Post, J., Veerman, J., Hamelers, J., Euverink, G., Metz, S., Nymeijer, D., \& Buisman, C. (2007). Salinity-gradient power: Evaluation of Salinity-gradient power: Evaluation of . Journal Of Membrane Science 288, 218-230.

Susanto, H., Fitrianingtyas, M., Samsudin, A. M., \& Syakur, A. (2017). Experimental study of the natural organic matters effect on the power generation of reverse electrodialysis. International of Energy Research, DOI: 10.1002/er.3728.

Tedesco, M., Brauns, E., Cipollina, A., Micale, G., Modica, P., Russo, G., \& Helsen, J. (2015). Reverse Electrodialysis with saline waters and concentrated brines: a laboratory investigation towards technology scale-up. Journal of Membrane Science, 492, https://doi.org/10.1016/j.memsci.2015.05.020.

Tedesco, M., Cipollina, A., Tamburini, A., \& Micale, G. (2017). Towards $1 \mathrm{~kW}$ power production in a reverse electrodialysis pilot plant with saline waters and concentrated brines. Journal of Membrane Science 522, 226-236.

Tedesco, M., Scalici, C., Vaccari, D., Cipollina, A., Tamburini, A., \& Micale, G. (2015). Performance of the first Reverse Electrodialysis pilot plant for power production from saline waters and concentrated brines. Journal of Membrane Science, DOI: http://dx.doi.org/10.1016/j.memsci.2015.10.057.

Veerman, J., Saakes, M., Metz, S., \& Harmsen, G. J. (2010). Electrical Power from Sea and River Water by Reverse Electrodialysis: A First Step from the Laboratory to a Real Power Plant. Environ. Sci. Technol, 44, 9207-9212.

Vermaas, D. A., Guler, E., Saakes, M., \& Nijmeijer, K. (2012). Theoretical power density fromsalinity gradients using reverse electrodialysis. Energy Procedia 20, 170-184.

Weiner, A. M., McGovern, R. K., \& Lienhard V, J. H. (2015). A new reverse electrodialysis design strategy which significantly reduces the levelized cost of electricity. Journal of Membrane Science 493, 605-614. 